\title{
Activity of $3 \beta$-hydroxysteroid dehydrogenase in the postovulatory follicle of the domestic fowl (Gallus domesticus)
}

\author{
D. G. Armstrong, Maida F. Davidson, A. B. Gilbert and J. W. Wells \\ Agricultural Research Council's Poultry Research Centre, \\ King's Buildings, West Mains Road, Edinburgh EH9 3JS, U.K.
}

\begin{abstract}
Summary. The activity of $\Delta^{5}-3 \beta$-hydroxysteroid dehydrogenase $(3 \beta-H S D)$ in the postovulatory follicle (POF) of the domestic hen was studied; it declined rapidly during the first $15 \mathrm{~h}$ after ovulation and then fell gradually until $50 \mathrm{~h}$ when there was no detectable activity. Comparison of $3 \beta$-HSD and glucose 6-phosphate dehydrogenase activities in the theca and granulosa cells indicated that the changes in enzymatic activity can be attributed to the thecal component; the enzyme activity in granulosa cells was stable up to $35 \mathrm{~h}$ after ovulation.

The results appear consistent with the hypothesis that the POF is a source of steroid hormones.
\end{abstract}

\section{Introduction}

Unlike the mammal, the bird does not have a true corpus luteum (see Gilbert, 1971a). The postovulatory follicle (POF) in the bird appears to regress uniformly for a period of 1 week (Davis, 1942) until it cannot be distinguished by the naked eye. The avian POF has no known function for most of this time, but it is physiologically active during the first $24 \mathrm{~h}$ of its life: its removal interferes with the oviposition of the egg derived from it (Rothchild \& Fraps, 1944a, b; Wood-Gush \& Gilbert, 1964) and causes disturbances in the associated nesting behaviour (Wood-Gush \& Gilbert, 1964; Gilbert \& Wood-Gush, 1972). The POF is well innervated (Gilbert, 1965) but neural mechanisms are of less importance than others in control of nesting, because denervated POFs (Gilbert \& Wood-Gush, 1965, 1969, 1970) have influences similar to those of intact follicles (Wood-Gush \& Gilbert, 1970, 1971).

Rothchild \& Fraps (1944a, b) postulated a hormonal secretion from the POF, and it has been claimed that injections of POF homogenate affect oviposition (Tanaka \& Nakada, 1974). Earlier studies showed that steroid dehydrogenase activity was present in the granulosa cells of the POF (Wyburn \& Baillie, 1966), and Furr (1969) and Senior \& Furr (1975) reported on the progesterone and oestrogen content, respectively, of the POF.

In an attempt to assess the capability of the POF as a steroid-producing structure and to relate this feature to its known physiology, we have investigated the enzymatic activity of the POF during the $50 \mathrm{~h}$ after ovulation. The particular enzymes studied were: glucose 6-phosphate dehydrogenase (EC 1.1.1.49), an enzyme of the pentose phosphate cycle of carbohydrate metabolism which generates the NADPH required for steroid biosynthesis, and $3 \beta$-hydroxysteroid dehydrogenase

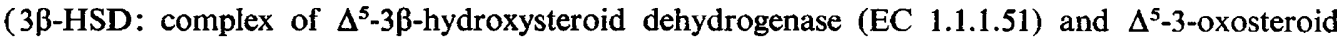
isomerase (EC 5.3.3.1)), an enzyme involved in the synthesis of steroid hormones.

\section{Materials and Methods}

Fifty hens derived from a commercial light-hybrid layer strain (Shaver) were used in the study. They were kept in individual cages in a controlled environment with $14 \mathrm{~h}$ light/day. Food and water 
were always available. The time of oviposition was recorded by a custom-built automatic timer which scanned every $60 \mathrm{sec}$. The output was fed to punched tape from which computer print-outs were obtained daily. A POF of the required age was obtained by selecting a hen at a specific time after oviposition.

The bird was killed by an intravenous overdose of sodium pentobarbitone (Nembutal: Abbott Laboratories), the body cavity was opened to expose the ovary and oviduct and the POF was removed immediately. The age of the POF was verified from its appearance and the position of the developing egg in the oviduct (Gilbert, 1971b): the accuracy of the method was probably about $\pm \frac{1}{2} \mathrm{~h}$ for POFs $<5 \mathrm{~h}$ old and $\pm 2 \mathrm{~h}$ for those $>25 \mathrm{~h}$.

\section{Histochemistry}

The POFs were snap-frozen in a $\mathrm{CO}_{2}$ /isopentane mixture $\left(-70^{\circ} \mathrm{C}\right)$. Cryostat sections were cut at $5 \mu \mathrm{m}$, air dried, and stained according to procedures described by Pearse (1972). Dehydroepiandrosterone (DHEA) and pregnenolone were used as substrates and $\mathrm{NAD}^{+}$as co-enzyme with Nitro blue tetrazolium chloride for the demonstration of $3 \beta-H S D$. Control sections without substrate or $\mathrm{NAD}^{+}$gave negligible staining.

The standard method for soluble enzymes was used to demonstrate glucose 6-phosphate dehydrogenase, with NADP $^{+}$as co-enzyme and Nitro blue tetrazolium chloride (Pearse, 1972). Sections were incubated at $37^{\circ} \mathrm{C}$ for $30 \mathrm{~min}$, rinsed briefly in distilled water, fixed for $5 \mathrm{~min}$ in $10 \%$ formalin, washed well and mounted with glycerin jelly. Counterstaining with neutral red aided visualization of the tissue, but this step was omitted when black and white photographs were to be taken, as it was difficult to distinguish the formazan granules clearly when the nuclei were stained.

\section{Histology}

Sections stained by conventional histological methods were used to obtain a more accurate interpretation of the histochemical results.

Formalin-fixed POFs were processed through to paraffin wax and $5-\mu \mathrm{m}$ sections were stained by standard techniques. The Alcian Blue or the periodic acid-Schiff procedures were used to stain the basal lamina which separates the granulosa from the theca.

To obtain some estimate of the area of the steroid-producing cells in the theca, $50 \times 50 \mathrm{~mm}$ transparencies were made from slides stained for $3 \beta-H S D$. These photographs were projected at an arbitrary but standard magnification on a sheet of paper and tracings were made of the areas occupied by the granulosa and thecal interstitial cells. The traced areas were cut out and weighed.

\section{Enzymatic assays}

Tissue preparation. Whole POFs and thecal tissue were flash-frozen in liquid nitrogen and stored at $-20^{\circ} \mathrm{C}$ until required. A $10 \%(\mathrm{w} / \mathrm{v})$ homogenate was prepared by grinding the tissue in liquid nitrogen and then homogenizing in a loose-fitting ground glass homogenizer with ice-cold $0.25 \mathrm{M}$ sucrose.

Granulosa cells were obtained by everting the POF on a Teflon pestle and gently scraping the exposed inside surface with the blunt side of a scalpel blade. The cells were then homogenized in ice-cold $0.25 \mathrm{M}$-sucrose using a tight-fitting ground glass homogenizer to give a final protein concentration of $0.5-1.0 \mathrm{mg} / \mathrm{ml}$. A portion of each scraped POF was examined histologically to confirm the removal of the granulosa tissue.

$3 \beta-H S D$. This enzyme was measured by a modification of the procedure described by Armstrong \& Wells (1976). A solution of the substrate, $\left[4-{ }^{14} \mathrm{C}\right]$ pregnenolone $(1.88 \mathrm{nmol}$; sp. act. $53 \mathrm{mCi} / \mathrm{mmol}$; Radiochemical Centre, Amersham) in $5 \mu$ redistilled ethanol, was mixed with $200 \mu 10.1 \mathrm{M}$-phosphatebuffered saline, $\mathrm{pH} 7 \cdot 2$, containing $0.2 \mu \mathrm{mol} \mathrm{NAD}{ }^{+}$. This mixture was warmed to $41^{\circ} \mathrm{C}$ and the cell-free homogenate $(50 \mu \mathrm{l})$ was added to start the reaction. After incubation for $10 \mathrm{~min}$ the reaction was stopped by adding acetone $(100 \mu \mathrm{l})$ containing $50 \mu \mathrm{g}$ pregnenolone and $50 \mu \mathrm{g}\left[{ }^{3} \mathrm{H}\right]$ progesterone 
(sp. act. $314 \mu \mathrm{Ci} / \mathrm{mmol}$ : Radiochemical Centre, Amersham; added as an internal standard). This mixture was extracted with $4 \mathrm{ml}$ methylene dichloride which was scparated and evaporated to dryness. The radioactive progesterone was separated from pregnenolone by partition chromatography on thin-layer silica gel and counted as described previously. The yield of product was calculated from the ${ }^{3} \mathrm{H} /{ }^{14} \mathrm{C}$ ratio. For each homogenate duplicate measurements were made with and without the addition of $0.8 \mathrm{~mm}-\mathrm{NAD}^{+}$. The expression of enzyme activity was based on the difference between these two measurements; one unit was defined as $1 \mu \mathrm{mol}$ product produced $/ \mathrm{min}$ at $41^{\circ} \mathrm{C}$.

Glucose 6-phosphate dehydrogenase. (a) Spectrophotometric assay: homogenates of the thecal portion were assayed at $41^{\circ} \mathrm{C}$ in a $1 \mathrm{~cm}$ path-length cuvette containing $2.9 \mathrm{ml}$ medium composed of $50 \mathrm{~mm}$-tris-HCl, pH 7.5, 5 mm-EDTA, 0.67 mm-glucose 6-phosphate and 0.5 mm-NADP ${ }^{+}$. The reaction was started by adding $100 \mu$ homogenate to the incubation medium and to a control cuvette containing the medium without glucose 6-phosphate. The increase in extinction at $340 \mathrm{~nm}$ was followed using a Unicam SP800 fitted with external recorder. (b) Fluorometric assay: this assay was developed to measure the activity in the granulosa homogenates. The medium $(500 \mu \mathrm{l})$ was warmed to $41^{\circ} \mathrm{C}, 50 \mu \mathrm{l}$ granulosa homogenate were added and incubated for $20 \mathrm{~min}$. The reaction was stopped by placing the tubes in an ice bath and adding $3 \mathrm{ml} 0.1 \mathrm{M}$-carbonate buffer, $\mathrm{pH} 10$. The fluorescence (excitation $340 \mathrm{~nm}$, emission $460 \mathrm{~nm}$ ) was measured in a Farrand Spectrofluorometer. The NADPH produced, and hence the enzyme activity, was calculated from a calibration curve obtained using NADPH standards.

\section{Protein and DNA}

These substances were measured by the methods described by Lowry, Rosebrough, Farr \& Randall (1951) and Schneider (1957).

\section{Statistical analysis}

The results were subjected to analysis of variance and the means were compared using the test of least significant difference. In samples where the Bartlett $\chi^{2}$ test showed heterogeneity of variances, the means were compared by Student's $t$ test.

\section{Results}

\section{Change in weight and $3 \beta-H S D$ activity of POFs}

After a significant fall between 0 and $10 \mathrm{~h}$ there was a continuing downward trend in the weight of the POF (Table 1). The declines in 3 $\beta$-HSD activity were significant up to $15 \mathrm{~h}$ after ovulation but there was little change thereafter (Table 1). The histochemical assessment of $3 \beta-H S D$ in the granulosa cells, based on deposition of a formazan dyestuff (Pl. 1, Fig. 3), confirmed the biochemical pattern (Table 2).

Table 1. Changes in the weight and total of $3 \beta-H S D$ activities of homogenates of hen postovulatory follicles (POFs) (means \pm S.E.M.)

\begin{tabular}{|c|c|c|c|c|c|c|c|c|}
\hline & \multicolumn{8}{|c|}{ Time after ovulation (h) } \\
\hline & $0-5$ & $6-10$ & $11-15$ & $16-20$ & $21-25$ & $30-35$ & $36-40$ & $41-45$ \\
\hline No. of follicles & 10 & 11 & 5 & 6 & 4 & 8 & 2 & 4 \\
\hline Wt of POF (g) & $\begin{array}{l}0.56 \\
\pm 0.03^{*}\end{array}$ & $\begin{array}{l}0.42 \\
\pm 0.03\end{array}$ & $\begin{array}{l}0.34 \\
\pm 0.04\end{array}$ & $\begin{array}{l}0.32 \\
\pm 0.03\end{array}$ & $\begin{array}{l}0.28 \\
\pm 0.04\end{array}$ & $\begin{array}{l}0.27 \\
\pm 0.03\end{array}$ & $\begin{array}{l}0.31 \\
\pm 0.06\end{array}$ & $\begin{array}{l}0.22 \\
\pm 0.04\end{array}$ \\
\hline $\begin{array}{l}\text { 3ß-HSD activity } \\
\text { (munits) }\end{array}$ & $\begin{array}{l}7.05 \\
\pm 0.65 \dagger\end{array}$ & $\begin{array}{l}4.63 \\
\pm 0.68\end{array}$ & $\begin{array}{l}2.02 \\
\pm 0.24\end{array}$ & $\begin{array}{l}\overline{2.36} \\
\pm 0.22\end{array}$ & $\begin{array}{l}\overline{1} \cdot 11 \\
\pm 0.26\end{array}$ & $\begin{array}{l}\overline{1} .66 \\
\pm 0.43\end{array}$ & $\begin{array}{l}\overline{1.28} \\
\pm 0.63\end{array}$ & $\begin{array}{l}1.26 \\
\pm 0.39\end{array}$ \\
\hline
\end{tabular}


Table 2. Classification of staining intensity of granulosa cells in hen postovulatory follicles using the tetrazolium histochemical reaction for detection of $3 \beta$-hydroxysteroid dehydrogenase activity

\begin{tabular}{cccc}
\hline & \multicolumn{3}{c}{ No. and activity of follicles } \\
\cline { 2 - 4 } Time after ovulation (h) & Strong positive & Weak positive & Negative \\
\hline $0-5$ & 8 & 0 & 1 \\
$6-10$ & 8 & 0 & 0 \\
$11-15$ & 3 & 3 & 0 \\
$16-20$ & 3 & 3 & 0 \\
$21-25$ & 0 & 3 & 1 \\
$30-35$ & 0 & 1 & 0 \\
$36-40$ & 0 & 3 & 8 \\
$>45$ & 0 & 0 & \\
\hline
\end{tabular}

Table 3. Biochemical measurements of enzymatic activities (mean \pm S.E.M.) in the granulosa and theca of the hen postovulatory follicle (POF)

\begin{tabular}{|c|c|c|c|c|c|c|c|c|c|}
\hline \multirow{3}{*}{$\begin{array}{c}\text { Time } \\
\text { after } \\
\text { ovulation } \\
\text { (h) }\end{array}$} & \multirow{3}{*}{$\begin{array}{c}\text { No. } \\
\text { of } \\
\text { POFs }\end{array}$} & \multicolumn{4}{|c|}{ 3ß-HSD activity } & \multicolumn{4}{|c|}{ Glucose 6-phosphate dehydrogenase activity } \\
\hline & & \multicolumn{2}{|c|}{$\begin{array}{c}\text { Total } \\
\text { (munits) }\end{array}$} & \multicolumn{2}{|c|}{$\begin{array}{c}\text { Specific } \\
\text { (munits/mg protein) }\end{array}$} & \multicolumn{2}{|c|}{$\begin{array}{c}\text { Total } \\
\text { (munits) }\end{array}$} & \multicolumn{2}{|c|}{$\begin{array}{c}\text { Specific } \\
\text { (munits/mg protein) }\end{array}$} \\
\hline & & Granulosa & Theca & Granulosa & Theca & Granulosa & Theca & Granulosa & Theca \\
\hline 1 & 6 & $0.83 \pm 0.03$ & $2.08 \pm 0.25 *$ & $0.58 \pm 0.03$ & $0.12 \pm$ & 107 & $456 \pm 80$ & $74 \cdot 6 \pm 12$ & $24 \cdot 6$ \\
\hline 10 & 5 & $0.82 \pm 0.02$ & $0.51 \pm 0.13$ & $0.64 \pm 0.05$ & $0.06 \pm 0.03$ & $110 \pm 18$ & $261 \pm 16 \dagger$ & $84 \cdot 6 \pm 14$ & $28 \cdot 8 \pm 3 \cdot 7$ \\
\hline 25 & 6 & $0.65 \pm 0.09$ & $0.58 \pm 0.08$ & $0.70 \pm 0.12$ & $0.08 \pm 0.02$ & $63 \pm 16$ & $159 \pm 22$ & $67 \cdot 2 \pm 12$ & $18.9 \pm 3.3$ \\
\hline 35 & 5 & $0.74 \pm 0.03$ & $0.18 \pm 0.02$ & $0.73 \pm 0.08$ & $0.03 \pm 0.01$ & $70 \pm 18$ & $140 \pm 24$ & $66 \cdot 5 \pm 14$ & $21 \cdot 5 \pm 3 \cdot 6$ \\
\hline
\end{tabular}

$* P<0.001$ when compared with $10 \mathrm{~h}$ POF.

$\dagger P<0.01$ when compared with $25 \mathrm{~h}$ POF.

Table 4. Enzymatic activity of the granulosa and theca cells of the hen postovulatory follicle (POF) expressed in terms of cell numbers (mean \pm S.E.M.)

\begin{tabular}{|c|c|c|c|c|c|c|}
\hline \multirow[b]{2}{*}{$\begin{array}{l}\text { Time } \\
\text { (h) }\end{array}$} & \multirow{2}{*}{$\begin{array}{l}\text { No. } \\
\text { of } \\
\text { POFs }\end{array}$} & \multicolumn{3}{|c|}{ Granulosa cells } & \multicolumn{2}{|c|}{ Thecal cells } \\
\hline & & $\begin{array}{l}\text { No. } \\
\left(\times 10^{-6}\right)\end{array}$ & $\begin{array}{c}\text { 3ß-HSD } \\
\text { ( } \mu \text { units } / 10^{6} \text { cells) }\end{array}$ & $\begin{array}{c}\text { G6PD } \\
\text { (munits } / 10^{6} \text { cells) }\end{array}$ & $\begin{array}{c}\text { 3ß-HSD } \\
\left(\mu \text { units } / 10^{6} \text { cells }\right) \dagger\end{array}$ & $\begin{array}{c}\text { G6PD } \\
\text { (munits } / 10^{6} \text { cells) } \dagger\end{array}$ \\
\hline 1 & 6 & $18.9 \pm 1.9^{*}$ & $46 \pm 5$ & $5 \cdot 9 \pm 1 \cdot 3$ & 110 & 24 \\
\hline 10 & 5 & $20 \cdot 7 \pm 2 \cdot 1$ & $41 \pm 3$ & $5 \cdot 5 \pm 1 \cdot 5$ & 25 & 13 \\
\hline 25 & 6 & $14.2 \pm 1.9$ & $51 \pm 1$ & $4.8 \pm 1.4$ & 41 & 11 \\
\hline 35 & 5 & $11 \cdot 4 \pm 2 \cdot 1$ & $81 \pm 18$ & $7 \cdot 7 \pm 1 \cdot 5$ & 16 & 12 \\
\hline
\end{tabular}

\section{EXPLANATION OF PLATE 1}

Fig. 1. The POF is a flattened cup-shaped structure. The section has been taken across its width: the lumen (L) is bounded on each side by the granulosa cells (GC), the theca interna (TI) and the theca externa (TE). Mallory trichome.

Fig. 2. Histochemical tetrazolium reaction using pregnenolone as substrate. The positive reaction is located in the granulosa and thecal interstitial cells.

Fig. 3. As for Fig. 2 but with DHEA as substrate. The reaction is more intense than with pregnenolone but the location is identical.

Fig. 4. As for Fig. 2 but with glucose 6-phosphate as substrate. Though mainly located in the granulosa and interstitial cells, some reaction was found throughout the theca interna. 

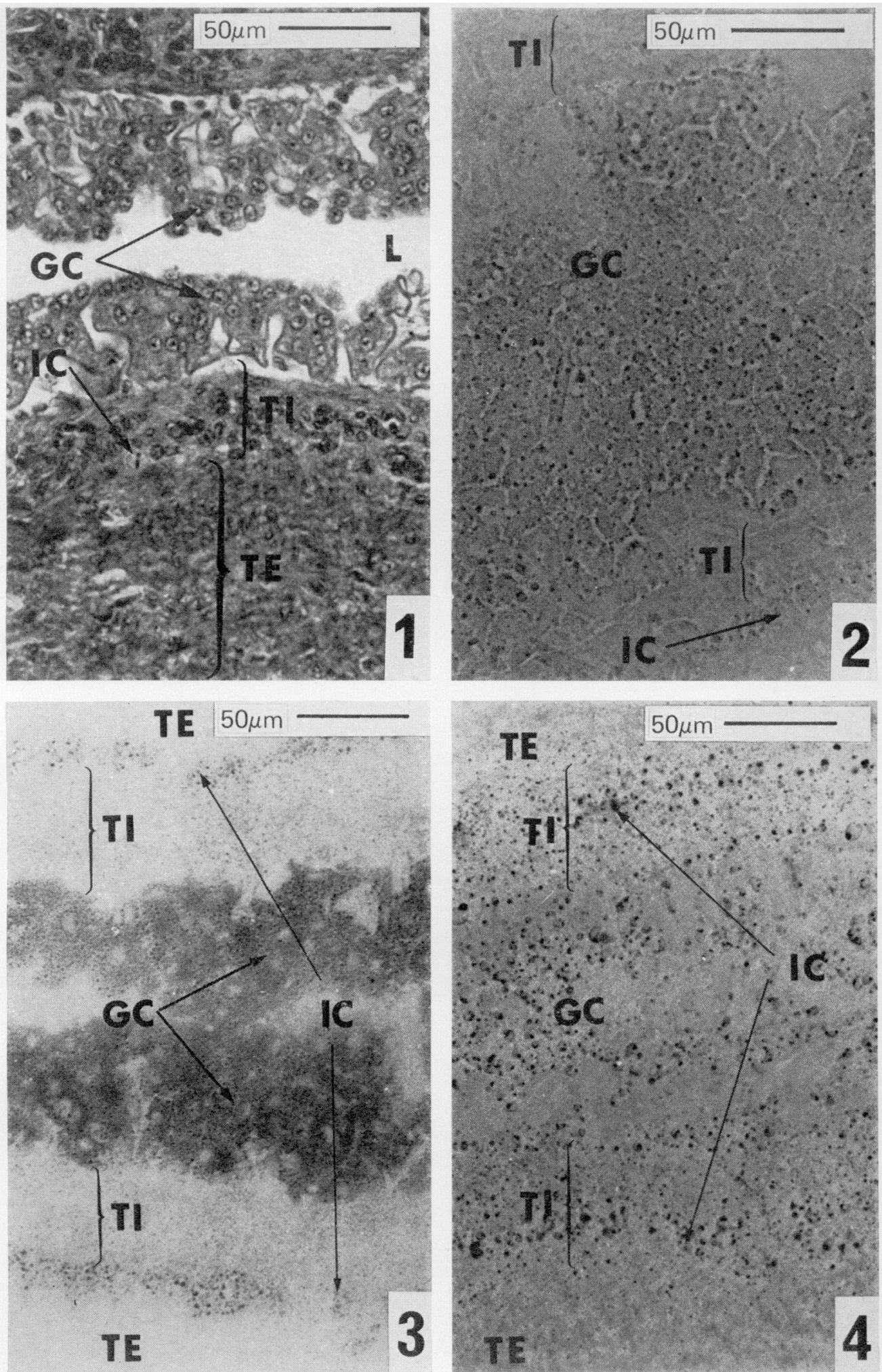

Hitisetr.256 


\section{Enzymatic activity in granulosa and theca cells}

The distribution of $3 \beta-H S D$ with pregnenolone as substrate was identical to that using DHEA, but the formazan deposit was not as intense (Pl. 1, Figs 2 and 3). The differences in the activities of $3 \beta$-HSD and glucose 6-phosphate dehydrogenase in each cell type are given in Table 3 . There were no changes for either enzyme in the granulosa cells during the first $35 \mathrm{~h}$ after ovulation. The enzymes in the theca declined over $25 \mathrm{~h}$ but the differences were small when the results were expressed as specific activity. However, only a small portion of the follicular wall tissue is involved in $3 \beta-H S D$ activity (Pl. 1, Fig. 3). The tracing method described above gave a rough estimate of the ratio of the areas of the granulosa and theca cells as $1: 1 \cdot 15$; the ratio did not differ significantly from $1: 1$. Using this assumption we compared the activities of $3 \beta$-HSD and glucose 6-phosphate dehydrogenase in $1 \times 10^{6}$ cells (based on DNA analyses of granulosa cells and assuming a DNA content of $2.5 \mathrm{pg} /$ cell; Davidson, 1969) of each type (Table 4). Again, although no changes were detected in the granulosa cells up to $35 \mathrm{~h}$ after ovulation, the activities of both enzymes in the theca decreased during the first $10 \mathrm{~h}$.

\section{Discussion}

The identity of the hormone(s) involved in the function of the POF is unknown. One hypothesis is that they are of a steroidal nature: this is suggested by the fact that injection of progesterone into oestrogen-primed pullets induces nesting behaviour of the type which is abolished in laying hens when POFs are ligated or removed (Wood-Gush \& Gilbert, 1975).

We chose to examine the alterations in activity of $3 \beta-H S D$ in the POF over several days because this enzyme has been shown to be a good indicator of steroid production in gonadal tissue (Albrecht, Koos \& Wehrenberg, 1975; Hay \& Moor, 1975). Furthermore, the enzyme is readily located in tissue by a well established histochemical procedure. The results demonstrate that rapid changes in weight and enzymatic activity occur in the POF during the first $10 \mathrm{~h}$ after ovulation; thereafter the decline is gradual to $45 \mathrm{~h}$ and by $50 \mathrm{~h}$ no activity is detected by histochemical or biochemical procedures. During this period there is a functional blood supply in the POF.

Biochemical measurements on granulosa and theca cell populations showed that the decline in $3 \beta$-HSD activity in homogenates of intact POFs (Table 1 ) can be attributed to changes in the thecal region. A difficulty encountered when comparing activity in the theca with that in the granulosa is that the active cells, the thecal interstitial cells (Gilbert, 1971a), form only a small part of the follicle wall (Fell, 1925). However, when equal numbers of the two cell types were compared (Table 4) the thecal portion of the POF again appeared responsible for the decline in activities of both enzymes studied.

The use of DHEA as a substrate in the histochemical reaction in the POF always gave a more intense deposit of formazan than did pregnenolone, although the locations of the deposits were similar. In the granulosa cell homogenates, however, the use of pregnenolone as substrate in the biochemical measurements indicated stable $3 \beta$-HSD levels (Table 3 ) while the qualitative histochemical assessment with DHEA revealed a decline in activity after $10 \mathrm{~h}$ (Table 2). The occurrence of two isoenzymes specific for each substrate, such as has been suggested for the human placenta (Ferre et al., 1975), cannot be discounted in the POF and should be resolved by kinetic studies using purified enzyme preparations.

Homogenates of intact POFs harvested during the first $5 \mathrm{~h}$ after ovulation (Table 1) always displayed a $3 \beta$-HSD activity much higher than the sum of the activities found in the separated granulosa and thecal portions (Table 3). A possible explanation of this discrepancy is the presence of an inhibitor. Serial dilution of a granulosa cell homogenate from POFs $1-10 \mathrm{~h}$ after ovulation gave rise to, at most, a 7 -fold increase in $3 \beta$-HSD activity at a 4 -fold dilution (D. G. Armstrong, unpublished observations). This dilution was the same as that used routinely for homogenates of intact POFs for $3 \beta$-HSD measurements. Homogenates of granulosa from $10 \mathrm{~h}$ and older POFs or of all thecal tissue showed no increase in $3 \beta$-HSD activity with different dilutions. Since the effect 
of the 'inhibitor' decayed by $50 \%$ after standing at $-20^{\circ} \mathrm{C}$ for 1 month, it is unlikely to be a nucleotide (see Lowry \& Passonneau, 1972) but may be a protein or a steroid. Wiener (1976) has demonstrated that the placental $3 \beta$-HSDs of various mammalian species also show changes in apparent activity with dilution and are strongly inhibited by $20 \alpha$-hydroxypregn-4-ene-3-one.

The evidence presented in this paper gives support to the suggestion that the avian POF produces steroid hormones during its functional phase. These hormones are likely to be involved in oviductal control and nesting behaviour.

We thank $\mathrm{Mr} \mathrm{H}$. R. Dick for his assistance in the measurement of glucose 6-phosphate dehydrogenase and DNA, and Mr P. H. Barker and Mr N. L. Watt for constructing the automatic egg-timer.

\section{References}

Albrecht, E.E., Koos, R.D. \& WehrenberG, W.B. (1975) Ovarian $\Delta^{5}-3 \beta$-hydroxysteroid dehydrogenase in the aged mouse during pregnancy. Biol. Reprod. 13, 158-162.

Armstrong, D.G. \& Wells, J.W. (1976) The measurement of $3 \beta$-hydroxysteroid dehydrogenase in ovaries of fowls (Gallus domesticus). Gen. comp. Endocr. 29, 313-318.

Davidson, J.N. (1969) The Biochemistry of the Nucleic Acids, p. 325. Methuen, London.

DAvis, D.E. (1942) Regression of the avian postovulatory follicle. Anat. Rec. 82, 297-304.

FELL, H.B. (1925) Histological studies on the gonads of the fowl. III. The relationship of the 'luteal' cell of the ovary of the fowl to the tissue occupying the atretic and discharged follicles, and the question of the homology of the latter tissue and the mammalian corpus luteum. Q. Jl microsc. Sci. 69, 591-609.

Ferre, F., Breulller, M., Cédard, L., Ducheone, M.J., Saintot, M., Descomps, B. \& Crastes de Paulet, A. (1975) Human placental $\Delta_{5}-3 \beta$ hydroxysteroid dehydrogenase activity ( $\left.\Delta_{5}-3 \beta H S D\right)$ : intracellular distribution, kinetic properties, retroinhibition and influence of membrane delipidation. Steroids 26, $551-570$.

FURR, B.J.A. (1969) A study of gonadotrophins and progestins in the domestic fowl. Ph.D. thesis, University of Reading.

Gilbert, A.B. (1965) Innervation of the ovarian follicle of the domestic hen. $Q$. Jl exp. Physiol. 50, 437-445.

Gilbert, A.B. (1971a) The endocrine ovary. In Physiology and Biochemistry of the Domestic Fowl, Vol. 3, pp. 1449-1468. Eds D. J. Bell \& B. M. Freeman. Academic Press, London.

GiLBERT, A.B. (1971b) Transport of the egg through the oviduct and oviposition. In Physiology and Biochemistry of the Domestic Fowl, Vol. 3, pp. 13451352. Eds D. J. Bell \& B. M. Freeman. Academic Press, London.

GilenerT, A.B. \& Wood-Gush, D.G.M. (1965) The control of the nesting behaviour of the domestic hen. III. The effect of cocaine in the post-ovulatory follicle. Anim. Behav. 13, 284-285.

Gilbert, A.B. \& WoOD-Gush, D.G.M. (1969) Innervation of ovarian transplants in the domestic hen. J. Reprod. Fert. 18, 550-551.
GilberT, A.B. \& Wood-Gush, D.G.M. (1970) Observations on ovarian transplants in the domestic fowl and their bearing on normal ovarian function. Res. vet. Sci. 11, 156-160.

GilberT, A.B. \& WoOD-Gush, D.G.M. (1972) The time of action of the post-ovulatory follicle in relation to nesting in two strains of hens. Revue du Comportement Animal 6, 223-224.

HAY, M.F. \& MOOR, R.M. (1975) Distribution of $\Delta^{5}$-3 $\beta$-hydroxysteroid dehydrogenase activity in the Graafian follicle of the sheep. J. Reprod. Fert. 43, 313-322.

Lowry, O.H. \& Passonneau, J.V. (1972) A Flexible System of Enzymatic Analysis, p. 122. Academic Press, London.

Lowry, O.H., Rosebrough, N.J., FARR, A.L. \& RANDALL, R.J. (1951) Protein measurement with the Folin phenol reagent. J. biol. Chem. 193, 265-275.

Pearse, A.G.E. (1972) Histochemistry, Theoretical and Applied, 3rd edn, Vol. 2. Churchill Livingstone, London.

ROTHCHILD, I. \& FRAPS, R.M. (1944a) On the function of the ruptured follicle of the domestic fowl. Proc. Soc. exp. Biol. Med. 56, 79-82.

RothChILD, I. \& FRAPS, R.M. (1944b) Relation between light-dark rhythms and hour of lay of eggs experimentally retained in the hen. Endocrinology 35, 355-362.

SCHNEIDER, W.C. (1957) Determination of nucleic acids in tissues by pentose analysis. In Methods in Enzymology, Vol. 3, pp. 680-684. Eds S. P. Colowick \& N. O. Kaplan. Academic Press, New York.

SenIor, B.E. \& FurR, B.J.A. (1975) A preliminary assessment of the source of oestrogen within the ovary of the domestic fowl. J. Reprod. Fert. 43, 241-247.

TANaka, K. \& Nakada, T. (1974) Participation of the ovarian follicle in control of time of oviposition in the domestic fowl. Poult. Sci. 53, 2120-2125.

WIENER, M. (1976) Control of placental $3 \beta$-hydroxy- $\Delta^{5}$ steroid dehydrogenase: comparison of enzyme characteristics in man, cow, goat, rat and rhesus monkey. Biol. Reprod. 14, 306-313.

Wood-GuSh, D.G.M. \& GilberT, A.B. (1964) The control of the nesting behaviour of the domestic hen. 11. The role of the ovary. Anim. Behav. 12, 451-453. 
Wood-Gush, D.G.M. \& GiLberT, A.B. (1970) The nesting behaviour of hens with ovarian transplants. Anim. Behav. 18, 52-54.

Wood-Gush, D.G.M. \& GILbERT, A.B. (1971) The role of the post-ovulatory follicle in nesting behaviour of hens with ovarian transplants. Revue du Comportement Animal 5, 273-275.

Wood-Gush, D.G.M. \& GilberT, A.B. (1975) The physiological basis of a behaviour pattern in the domestic hen. Symp. zool. Soc. Lond. 35, 261276.

WybuRN, G.M. \& Balllie, A.H. (1966) Some observations on the fine structure and histochemistry of the ovarian follicle of the fowl. In The Physiology of the Domestic Fowl, pp. 30-38. Eds C. Horton-Smith \& E. C. Amoroso. Oliver \& Boyd, Edinburgh.

Received 16 July 1976 